\title{
KOMPETENSI PEDAGOGIK GURU BAHASA JEPANG DALAM MELAKSANAKAN PEMBELAJARAN DILIHAT DARI PERSEPSI SISWA KELAS X DAN KELAS XI IBB DI SMA N 2 SINGARAJA
}

\author{
Damayanti, P. A. S ${ }^{1}$ Mardani, D. M. S ${ }^{2}$, dan Sadyana, W 3 \\ 123 Jurusan Pendidikan Bahasa Jepang, Universitas Pendidikan Ganesha, Singaraja,Bali \\ e-mail: ayuputu9993@gmail.com,desakmardani@undiksha.ac.id, wayan.sadyana@undiksha.ac.id
}

\begin{abstract}
Abstrak
Penelitian ini bertujuan untuk menganalisis kompetensi pedagogik guru bahasa Jepang dalam melaksanakan pembelajaran dilihat dari persepsi siswa kelas X dan kelas XI di SMA N 2 Singaraja. Penelitian ini merupakan penelitian deskriptif kualitatif. Subjek penelitian ini adalah siswa kelas $X$ dan kelas XI di SMA N 2 Singaraja. Metode pengumpulan data menggunakan kuesioner tertutup dan wawancara terbuka. Hasil penelitian menunjukkan bahwa persepsi siswa terkait kompetensi pedagogik guru bahasa Jepang dalam melaksanakan pembelajaran sangat baik. Dibuktikan dengan persentase jawaban siswa yang menyatakan terkait kompetensi pedagogik secara umum yaitu $70,32 \%$ siswa menyatakan sangat baik dan $26,67 \%$ siswa menyatakan baik. Berdasarkan hasil wawancara, menyatakan bahwa guru bahasa Jepang mampu melaksanakan pembelajaran yang mendidik, mampu mengenali karakteritik peserta didik, guru bahasa Jepang mampu berkomunikasi dengan sopan, baik dalam pembelajaran di kelas atau berkomunikasi secara langsung, guru bahasa Jepang mampu melaksanakan penilaian dengan tepat secara objektif. Dari beberapa hal positif yang dimiliki oleh guru dalam mengajar, ada hal yang perlu ditingkatkan yaitu guru bahasa Jepang diharapkan dapat mengembangkan potensi yang dimiliki peserta didik dengan maksimal.
\end{abstract}

Kata Kunci: Kompetensi pedagogik, persepsi, persentase

\section{要旨}

本研究の目的は、シンガラジャ第二国立高校において、一年生と二年生の学習者により、日 本語教師の学習実践に教育的な能力についての評価がどのようなことかを明らかにする。こ のデータを定性的記述法により分析した。調查協力者は、シンガラジャ第二国立高校におけ る一年生と二年生の学習者である。調査対象は、インタビューと個人アンケートより収集し たデータである。このデータを分析した結果、日本語教師の学習実践に教育的な能力につい ての評価について、学習者による日本語教師の学習実践に教育的な能力についての評価は、 良かった。それは、91人の内、回答者の $70.32 \%$ 「王本語教師の教育能力が非常に良 い」、26.67\%が「日本語教師の教育能力が良い」だということが分かった。 教育の学習を実施することができ，学習者の性格を認識することができる。日本語教師は教 室で直接コミュニケーション または 丁寧な言葉で コミュニケーションをすることが できる。日本語教師は適切に評価を実施することができる。先生が教えているいくつかの肯 定的なことから、改善が必要なことがいくつかある。日本語教師は 最大で 学習者の能力 を発することができると期待される。

キーワード：学習実践に教育的な能力、評価、パーセンテージ

\section{Pendahuluan}

Perkembangan pembelajaran bahasa Jepang dalam dunia pendidikan bisa dikatakan cukup pesat. Hasil survei yang dilakukan oleh Japan Foundation pada tahun 2015 tentang pendidikan bahasa Jepang menyatakan bahwa jumlah pelajar bahasa Jepang di luar Jepang mencapai 3.56 juta orang. Indonesia menjadi salah satu Negara yang jumlah pembelajar bahasa Jepang terbanyak mencapai 872.441 orang. Jumlah ter $\neg$ sebut didominasi oleh 
siswa Sekolah Menengah Atas (SMA) yakni sebanyak $40 \%$. SMA N 2 Singaraja merupakan salah satu sekolah yang menyumbang pembelajar bahasa Jepang dari $40 \%$ pembelajar tersebut.

Bahasa Jepang masuk dalam kurikulum pendidikan, dalam upaya untuk menghasilkan SDM yang mampu berbahasa Jepang dan menciptakan SDM yang berkualitas yang mampu bersaing di kancah nasional maupun internasional. Untuk menghasilkan SDM yang berkualitas di bidang bahasa Jepang salah satunya melalui pendidikan. Pendidikan merupakan sebuah jembatan yang akan mengantarkan seseorang mencapai apa yang menjadi tujuan pendidikan. Saat ini dalam mewujudkan keberhasilan pencapaian tujuan pendidikan nasional tidak hanya dipengaruhi oleh kurikulum saja, melainkan komponen pendidikan lain seperti pendidik.

Guru sebagai pendidik memiliki peran yang sangat penting dalam proses belajar dan kualitas siswa sangat bergantung pada mutu guru. Guru yang baik adalah guru yang memiliki kompetensi guru yang baik pula. Rezeki (2015) menyatakan bahwa kemampuan atau kompetensi guru adalah seperangkat penguasaan kemampuan yang harus ada dalam diri guru agar dapat mewujudkan kinerjanya secara tepat dan efektif.

Dalam Undang-Undang Republik Indonesia nomor 14 tahun 2005 tentang Guru dan Dosen, mengisyaratkan bahwa guru adalah pendidik profesional dengan tugas utama mendidik, mengajar, membimbing, mengarahkan, melatih, menilai, dan mengevaluasi siswa pada pendidikan anak usia dini jalur pendidikan formal, pendidikan dasar, dan pendidikan menengah.

Kompetensi pedagogik yaitu kemampuan yang harus dimiliki guru berkenaan dengan karakteristik siswa dilihat dari berbagai aspek seperti fisik, moral, sosial, kultural, emosional, dan intelektual (Wendra, 2015). Kompetensi pedagogik sangat penting dimiliki dan dikuasai dengan baik oleh seorang guru karena dalam kompetensi ini guru dituntut harus memiliki landasan pengetahuan yang kuat yang digunakan dalam mengelola proses belajar peserta didik secara utuh untuk memperoleh hasil yang maksimal. Teori tersebut sejalan dengan teori yang dikemukakan oleh Fattah (2013) menyatakan bahwa guru sebagai sebuah profesi yang sangat strategis dalam pembentukan dan pemberdayaan anak-anak penerus bangsa dengan segala potensi yang dimiliki, memiliki peran dan fungsi yang semakin signifikan dimasa mendatang.

Sebagai seorang guru harus mampu menyampaikan pengetahuan yang ia miliki ke siswa dengan baik. Melihat bahwa saat ini terjadi perubahan paradigma dalam dunia pendidikan, dimana diterapkannya kurikulum 2013 menggunakan pendekatan saintifik dalam hal ini siswa dituntut berperan aktif dalam mengikuti proses pembelajaran. Siswa harus lebih banyak berperan dalam menemukan sendiri pengetahuan, guru hanya sebagai fasilitator saja. Selain itu, saat ini guru tidak hanya berperan dalam membangun kemampuan berpikir kritis siswa saja, tetapi harus mampu membangun aspek lain seperti aspek psikologis siswa.

Guru bahasa Jepang di SMA N 2 Singaraja, merupakan Guru bahasa Jepang yang sudah mengetahui dan menerapkan teori - teori belajar serta prinsip-prinsip pembelajaran yang mendidik jika dilihat dalam proses pembelajaran yang berlangsung. Dilihat dari umur guru bahasa Jepang yang bisa dikategorikan sebagai guru muda namun memiliki pengalaman mengajar yang cukup di bidangnya. Guru bahasa Jepang SMA N 2 Singaraja juga merupakan lulusan dari jurusan Pendidikan bahasa Jepang, hal tersebut yang membedakan dengan guru bahasa Jepang di SMA lainnya yang sebagian besar latar belakang pendidikannya bukan dari pendidikan bahasa Jepang.

Berdasarkan observasi awal yang dilakukan pada Sabtu, 20 Mei 2017 di SMA N 2 Singaraja aktivitas pembelajaran bahasa Jepang di kelas $X$ dan kelas XI IBB berlangsung cukup baik, hal ini dapat dilihat dari sikap aktif siswa dalam pembelajaran. Dari awal dimulainya pelajaran siswa dapat memfokuskan perhatiannya ke guru. Hal ini dibuktikan dengan antusias para siswa dalam proses pembelajaran. Di tengah proses belajar mengajar sebagian besar siswa dapat memusatkan perhatian ke guru saat memberikan materi, mereka juga bersikap tertib dan semangat, walaupun tidak sedikit siswa yang kurang paham dan tidak memperhatikan penjelasan guru dengan baik. 
Guru yang memenuhi kualifikasi dan kompetensi keguruan akan mendukung dan menggerakkan semangat belajar siswa, karena guru diharapkan dapat memfasilitasi pengembangan potensi akademik dan Kualitas pembelajaran yang baik tidak terlepas dari peran penting guru saja, tetapi juga siswanya. Siswa merupakan individu yang turut aktif dalam pembelajaran, salah satunya siswa dapat memberikan penilaian, masukan dan saran dari pembelajaran yang telah diberikan oleh guru. Guru yang sudah merasa bahwa dirinya sudah memenuhi kualifikasi sebagai tenaga pendidik, belum tentu cara pengajarannya akan mudah dipahami oleh siswa. Begitu juga sebaliknya, tidak selalu guru yang merasa kurang dalam kompetensinya, pembelajaran yang diberikan ke siswa akan sulit untuk dipahami.

Siswa dapat mempersepsi atau memberikan penilaian terhadap kemampuan guru dalam melaksanakan pembelajaran. Walgito (2015) menyatakan proses terjadinya persepsi diawali dengan penerimaan stimulus oleh indera dari apa yang diamati. Dalam hal ini yaitu dalam proses pembelajaran yang dilakukan guru, kemudian diteruskan ke dalam otak untuk diberi arti sehingga siswa mengerti dan memahami. Selanjutnya hasil interpretasi dari proses tersebut akan mempengaruhi pemberian respon, penilaian, atau tindakan siswa tersebut.

Penelitian sejenis pernah dilakukan oleh Tirtanigrum (2015) dengan judul "Kompetensi Pedagogik Dosen Jurusan Pendidikan Bahasa Jepang dalam Melaksanakan Pembelajaran dilihat dari Persepsi Mahasiswa Semester Empat di Jurusan Pendidikan Bahasa Jepang Fakultas Bahasa dan Seni Universitas Pendidikan Ganesha Tahun Ajaran 2013/2014". Penelitian sejenis lainnya dilakukan oleh Fattah (2013) dengan judul "Kompetensi Pedagogik Guru Bahasa Arab Madrasah Aliyah Se Kota Samarinda"

Mengingat akan pentingnya kompetensi pedagogik yang harus dimiliki oleh seorang guru, maka sudah sangat wajib bagi seorang guru untuk mengetahui aspek-aspek dalam kompetensi pedagogik. Sehubungan dengan hal tersebut, persepsi siswa kelas $\mathrm{X}$ dan kelas XI IBB tentang pelaksanaan pembelajaran yang dilakukan oleh guru bahasa Jepang sangat perlu untuk diidentifikasi untuk mengetahui kompetensi pedagogik guru bahasa Jepang dari sudut pandang siswa sebagai penerima pembelajaran di kelas.

\section{Metode}

Pada metode penelitian dilakukan enam langkah diantaranya, pendekatan dan jenis penelitian, lokasi penelitian, sumber data, metode dan instrumen pengumpulan data, metode dan teknis analisis data, dan pengecekan keabsahan data. Berikut penjabarannya.

Pendekatan penelitian yang digunakan berupa pendekatan deskriptif kualitatif yang menekankan pada menggali informasi sebagai data penelitian secara deskriptif untuk menjawab pertanyaan penelitian. Data utama yang diperoleh melalui pengumpulan data berdasarkan kuesioner tertutup yang diuji cobakan ke 91 responden kemudian akan dianalisis, dipersentasekan dideskripsikan secara kualitatif. Data tambahan atau pendukung yang diproleh melalui wawancara

Penelitian ini dilaksanakan pada kelas X dan kelas XI SMA Negeri 2 Singaraja yang berlokasi di Jalan Srikandi, Singaraja. Pemilihan tempat penelitian ini didasarkan pada pertimbangan bahwa di sekolah ini terdapat pembelajaran bahasa Jepang sesuai dengan kurikulum yang telah ditetapkan dan melihat kemampuan guru dalam kegiatan pembelajaran menggunakan metode dan model pembelajaran yang menarik sehingga siswa juga ikut antusias dalam mengikuti pembelajaran.

Sumber data yang paling utama dalam penelitian ini adalah hasil dari pengisian kuesioner tentang persepsi terhadap kompetensi pedagogik guru bahasa Jepang dalam proses pembelajaran. Kuesioner diisi oleh responden sendiri yaitu siswa kelas $X$ dan kelas XI SMA Negeri 2 Singaraja yang secara keseluruhan berjumlah 91 orang. Dalam penelitian ini terdapat data tambahan seperti wawancara yang dilakukan bersama siswa kelas $X$ dan kelas XI dengan menunjuk siswa atau responden yang memberikan pernyataan tidak setuju pada pengisian kuesioner.

Untuk memperoleh data yang baik dan akurat dalam penelitian ini beberapa instrumen yang digunakan dalam penelitian ini, yaitu berupa kuesioner dan wawancara.

1. Kuesioner 
Dalam instrumen ini berisi beberapa butir pernyataan untuk diberi tanggapan oleh responden mengenai objek yang diteliti dengan lima alternatif jawaban. Penelitian ini menggunakan kuesioner tertutup.

Alternatif jawaban yang disediakan yaitu Sangat Setuju (5), Setuju (4), Tidak , Cukup Setuju (3), Tidak Setuju (2), dan Sangat Tidak Setuju (1). Mengingat bahwa setiap variabelnya diukur dengan kuesioner dengan skor terendah 1 dan skor tertinggi 5 , maka skor total yang diperoleh ditransformasi menjadi persentase dengan kriteria yang ditentukan sebagai berikut:

Persentase Tertinggi $=\frac{5}{5} \times 100 \%=100 \%$

Persentase Terendah $=\frac{1}{5} \times 100 \%=20 \%$

Rentang $=$ persentase tertinggi - persentase terendah $=100 \%-20 \%=80 \%$

Panjang Kelas Interval $=\frac{\text { Rentang }}{\text { Banyak data }} \frac{80 \%}{5}=16 \%$

Dengan demikian panjang setiap kelas intervalnya adalah $16 \%$ sehingga dapat dibuat kelas interval sebagai berikut:

\section{Tabel Kriteria Persentase}

\begin{tabular}{c|c|c}
\hline No & Interval & Kriteria \\
& & \\
\hline 1 & $84 \%-$ & Sangat \\
& $100 \%$ & Baik \\
\hline 2 & $68 \%-$ & Baik \\
& $83 \%$ & \\
\hline 3 & $52 \%-$ & Sedang \\
& $67 \%$ & \\
\hline 4 & $36 \%-$ & Kurang \\
& $51 \%$ & \\
\hline 5 & $20 \%-$ & Sangat \\
& $35 \%$ & Kurang \\
\hline
\end{tabular}

(Sumber: Modifikasi dari Riduwan, 2011:89)

Hasil penelitian diperoleh melalui pengolahan data kuesioner yang berupa persentase jawaban responden. Data dihitung menggunakan rumus persentase sebagai berikut:

Keterangan:

Menghitung persentase skor responden secara keseluruhan dengan rumus sebagai berikut:

$\mathrm{P}=\frac{n}{N} \times 100$

Keterangan:

$\mathrm{P}=$ Persentase

$\mathrm{n}=$ nilai yang diperoleh

$\mathrm{N}=$ total nilai

Menghitung persentase jawaban responden per item atau per pernyataan pada tiap-tiap komponen akan di hitung sebagai berikut :

$P=\frac{N}{X} \times 100 \%$

Keterangan:

B: bobot nilai pilihan jawaban angket

$\mathrm{X}$ : jumlah responden 


\section{F: frekuensi jawaban responden \\ $\mathrm{P}$ : persentase \\ $\mathrm{N}$ : nilai yang diperoleh $(\mathrm{BxF})$}

(Sumber: Arikunto, 2010)

\section{Wawancara}

Panduan wawancara digunakan sebagai panduan tentang pelaksanaan wawancara agar dapat berlangsung sesuai dengan apa yang diharapkan. Dalam persiapan wawancara selain menyusun pedoman, yang sangat penting adalah membina hubungan baik dengan responden (Sukmadinata, 2008). hubungan baik dengan responden (Sukmadinata, 2008).

Wawancara dilakukan dengan lima orang siswa, pemilihan lima orang siswa didasarkan pada skor pada pengisian kuesioner. Terdapat 3 orang siswa dengan skor tertinggi, dan 2 orang siswa dengan skor terendah. Pemilihan siswa dengan skor tertinggi lebih banyak dipilih saat wawancara, dikarenakan menyesuaikan dengan persentase pada hasil kuesioner. Wawancara terbuka dan mendalam dilakukan dengan mewawancarai lima orang siswa pada hari senin 12 Maret 2018.

Metode dan teknik Analisis data yang digunakan bertujuan untuk mendapatkan gambaran tentang persepsi siswa terhadap kompetensi pedagogik guru bahasa Jepang di SMA N 2 Singaraja. Teknik analisis yang dilakukan dengan menggunakan beberapa cara sebagai berikut:

1. Reduksi Data

Reduksi data merupakan proses pemilihan, pemusatan perhatian, pengabstraksian dan pentransformasian data kasar dari lapangan. Proses ini berlangsung selama penelitian ini dilakukan, dari awal sampai akhir penelitian. Data yang diproleh melalui observasi awal, penyebaran kuesioner dan wawancara akan diklasifikasikan agar memudahkan dalam penyajian data

2. Penyajian Data

Penyajian data adalah sekumpulan informasi tersusun yang memberi kemungkinan untuk menarik kesimpulan dan pengambilan tindakan. Bentuk penyajian data dalam penelitian ini ialah berupa tabulasi data, dimana data yang diproleh akan akan disajikan kedalam bentuk diagram dan dipersentasekan kemudian akan dijelaskan ke dalam bentuk teks deskriptif.

3. Menarik Kesimpulan atau Verifikasi

Dalam tahap ini, peneliti membuat rumusan proposisi yang terkait dengan prinsip logika, mengangkatnya sebagai temuan penelitian, kemudian dilanjutkan dengan mengkaji secara berulang-ulang terhadap data yang telah didapat melalui kuesioner dan wawancara, pengelompokkan data yang telah terbentuk sehingga sampai pada penarikan kesimpulan.

Dalam penelitian ini, keabsahan data dilakukan dengan teknik triangulasi. Triangulasi adalah teknik pemeriksaan keabsahan data yang memanfaatkan sesuatu yang lain dalam membandingkan data yang telah diperoleh terhadap objek penelitian. Jadi, dalam penelitian ini untuk mengecek keabsahan data dilakukan melalui dua proses triangulasi sebagai berikut:

1. Triangulasi Teknik

Triangulasi teknik untuk menguji kredibilitas data dilakukan dengan cara mengecek data kepada sumber yang sama dengan teknik yang berbeda. Bila dengan teknik pengujian kredibilitas data kuesioner tersebut menghasilkan hasil yang kurang jelas maka peneliti melakukan pengambilan data lebih lanjut kepada sumber data dengan teknik wawancara. Proses ini bertujuan untuk membandingkan serta melihat persamaan antara data hasil pengisian kuesioner dan data hasil wawancara sehingga keabsahan data dapat dipertanggungjawabkan. 


\section{Hasil dan Pembahasan \\ Kompetensi pedagogik guru bahasa Jepang secara umum}

Persepsi siswa tentang kompetensi pedagogik guru bahasa Jepang secara umum diperoleh skor tertinggi 100 dan skor terendah adalah 73,88. Dari 91 responden 70,32\% responden menyatakan bahwa kompetensi pedagogik guru bahasa Jepang sangat baik dan $29,67 \%$ menyatakan bahwa kompetensi pedagogik guru bahasa Jepang baik. Berdasarkan data penelitian tersebut dapat digambarkan dalam diagram lingkaran sebagai berikut:

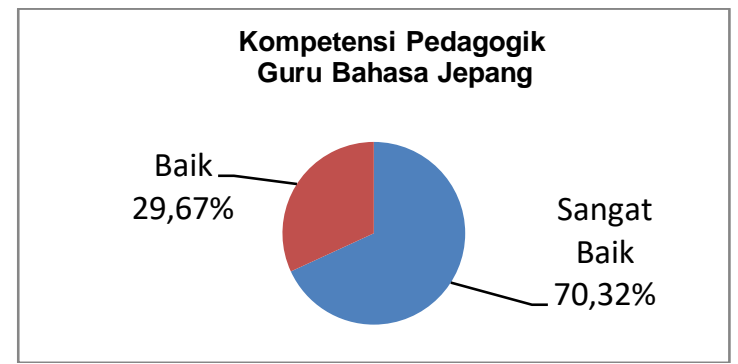

Gambar 1. Diagram Kompetensi pedagogik guru bahasa Jepang

Dari gambar tersebut menunjukkan bahwa dari 91 responden diketahui bahwa kompetensi pedagogik bahasa Jepang secara umum yang terdiri dari 36 pernyataan menyatakan bahwa 70,32\% responden menyatakan bahwa kompetensi pedagogik guru bahasa Jepang sangat baik dan $29,67 \%$ responden menyatakan bahwa kompetensi pedagogik guru bahasa Jepang baik.

\section{Kompetensi Pedagogik Guru bahasa Jepang pada Tiap-tiap Komponen}

1. Menguasai Teori Belajar dan Prinsip-prinsip Pembelajaran yang Mendidik serta Mampu Melaksanakan Pembelajaran yang mendidik

Hasil analisis data penelitian menunjukkan bahwa pada komponen pertama diperoleh skor tertinggi 100 dan skor terendah adalah 67,77. Dari 91 responden diketahui bahwa $61,53 \%$ responden menyatakan bahwa kompetensi pedagogik guru bahasa Jepang dalam komponen pertama sangat baik dan 39,56\% responden menyatakan bahwa kompetensi pedagogik guru bahasa Jepang baik.

2. Mengenali Karakteristik Peserta didik

Hasil analisis data penelitian menunjukkan bahwa pada komponen kedua diperoleh skor tertinggi 100 dan skor terendah adalah 76. Dari 91 responden diketahui bahwa $81,31 \%$ responden menyatakan bahwa kompetensi pedagogik guru bahasa Jepang dalam komponen kedua sangat baik dan $18,68 \%$ responden menyatakan bahwa kompetensi pedagogik guru bahasa Jepang baik.

3. Berkomunikasi dengan peserta didik

Hasil analisis data penelitian menunjukkan bahwa pada komponen ketiga diperoleh skor tertinggi 100 dan skor terendah adalah 65. Dari 91 responden diketahui bahw a $83,51 \%$ responden menyatakan bahwa kompetensi pedagogik guru bahasa Jepang dalam komponen ketiga sangat baik dan 16,48\% responden menyatakan bahwa kompetensi pedagogik guru bahasa Jepang baik.

4. Mengembangkan Potensi Peserta didik

Hasil analisis data penelitian menunjukkan bahwa pada komponen keempat diperoleh skor tertinggi 100 dan skor terendah adalah 60. Dari 91 responden diketahui bahwa $63,73 \%$ responden menyatakan bahwa kompetensi pedagogik guru bahasa Je pang dalam komponen keempat sangat baik dan $36,26 \%$ responden menyatakan bahwa kompetensi pedagogik guru bahasa Jepang baik.

5. Melaksanakan Penilaian

Hasil analisis data penelitian menunjukkan bahwa pada komponen kelima diperoleh skor tertinggi 100 dan skor terendah adalah 60. Dari 91 responden diketahui bahwa $68,13 \%$ responden menyatakan bahwa kompetensi pedagogik guru bahasa Jepang dalam komponen kelima sangat baik dan $31,86 \%$ responden menyatakan bahwa kompetensi pedagogik guru bahasa Jepang baik. 


\section{Kompetensi Pedagogik Guru Bahasa Jepang Ditinjau dari Tiap-tiap Pernyataan Pada tiap-tiap Komponen}

Pada komponen pertama yang terdiri dari 18 pernyataan (nomor 1 sampai nomor 18), persentase jawaban tertinggi terdapat pada pernyataan no 1 terkait Guru mengawali pembelajaran dengan baik dengan berinteraksi awal dengan 3S (Senyum,Salam,Sapa) yaitu sebesar $99,77 \%$ dengan jumlah responden menjawab sangat setuju sebanyak $88 \%$, setuju sebanyak $12 \%$. Persentase jawaban terendah pada komponen pertama yaitu terdapat pada pernyataan no 10 terkait guru menggunakan media, alat peraga atau gesture untuk memperjelas tema dan menarik perhatian siswa ke pembelajaran sebesar $83,82 \%$ dengan jumlah responden menjawab sangat setuju sebanyak $33 \%$, setuju $49 \%$, cukup setuju $12 \%$ dan tidak setuju sebanyak $6 \%$. Namun jika dilihat dari persentase jawaban yang menyatakan tidak setuju yaitu sebanyak $6 \%$.

Pada komponen kedua yang terdiri dari 5 pernyataan (nomor 19 sampai nomor 23), persentase jawaban tertinggi terdapat pada pernyataan no 21 terkait guru sering memberikan bimbingan dan memotivasi siswa tanpa membeda-bedakan sebesar $92,80 \%$ dengan jumlah responden yang menjawab sangat setuju sebesar $57 \%$, setuju $40 \%$, dan cukup setuju sebanyak $3 \%$. Persentase jawaban terendah pada komponen kedua terdapat pada pernyataan no 22 terkait guru mampu membantu mengembangkan potensi dan mengatasi kekurangan siswa yaitu sebesar $84,26 \%$ dengan jumlah responden yang menjawab sangat setuju sebesar $48 \%$, setuju $48 \%$, cukup setuju $3 \%$ dan tidak setuju sebanyak $1 \%$.

Pada komponen ketiga yaitu terkait kemampuan mengenali karakteristik peserta didik yang terdiri dari 4 pernyataan (nomor 24 sampai nomor 27), persentase jawaban tertinggi terdapat pada pernyataan no 24 terkait guru memiliki kemampuan untuk berkomunikasi secara efektif sebesar $95,05 \%$, dengan jumlah responden yang menjawab sangat setuju sebanyak $65 \%$, setuju $34 \%$, cukup setuju $1 \%$. Persentase jawaban terendah terdapat pada pernyataan no 25 terkait guru memiliki kemampuan untuk berkomunikasi secara santun yaitu sebesar $90,11 \%$, dengan jumlah responden yang menjawab sangat setuju sebanyak $50 \%$, setuju $48 \%$, cukup setuju $2 \%$.

Pada komponen keempat terdiri dari dua pernyataan yaitu (nomor 28 sampai nomor 29).Total persentase tertinggi terdapat pada pernyataan no 29 terkait guru memberikan siswa kesempatan untuk mengembangkan potensi yang dimiliki melalui pembelajaran yang mendukung baik dalam bidang akademik, sosial, kepribadian maupun dalam hal kreativitas siswa sebesar $98,29 \%$ dengan jumlah responden menjawab sangat setuju sebanyak $55 \%$, setuju $37 \%$, cukup setuju $8 \%$ Total persentase terendah yaitu terdapat pada no 28 terkait guru mampu memahami potensi siswa di dalam pembelajaran dengan baik yaitu sebesar $91,46 \%$,dengan jumlah responden menjawab sangat setuju sebanyak $55 \%$, setuju $37 \%$, dan cukup setuju sebanyak $8 \%$.

Pada komponen kelima yang terdiri dari tujuh pernyataan yaitu (nomor 30 sampai nomor 36). Total persentase tertinggi terdapat pada pernyataan no 36 terkait secara umum strategi penilaian dalam pembelajaran baik dan efektif yaitu sebesar $92,80 \%$ dengan jumlah responden menjawab sangat setuju sebanyak $59 \%$, setuju $35 \%$, dan cukup setuju $6 \%$. Total persentase terendah terdapat pada pernyataan no 32 terkait jenis penilaian yang digunakan oleh guru sesuai dengan kemampuan siswa sebesar $80,67 \%$, dengan jumlah responden menjawab sangat setuju sebanyak $49 \%$, setuju $45 \%$,dan cukup setuju sebanyak $6 \%$.

\section{PEMBAHASAN}

\section{Kompetensi pedagogik guru bahasa Jepang secara umum}

Persentase jawaban responden yang menyatakan bahwa kompetensi pedagogik guru bahasa Jepang sangat baik yaitu sangat tinggi sebesar 70,32 \% menandakan bahwa kemampuan guru tersebut dalam mengajar di dalam kelas baik dan sesuai dengan kompetensi keguruan yang seharusnya dimiliki oleh seorang guru. Hal ini sesuai dengan teori yang dinyatakan oleh Wendra (2015), bahwa kemampuan dalam kompetensi pedagogik guru harus menguasai beberapa hal sebagai berikut yaitu penguasaan terhadap peserta didik, penguasaan terhadap teori belajar dan prinsip-prinsip pembelajaran yang mendidik, 
mampu mengembangkan kurikulum sesuai dengan bidang yang diampu, menyelenggarakan pembelajaran yang mendidik, mampu mengembangkan potensi peserta didik, mampu berkomunikasi dengan peserta didik dan mampu melaksanakan penilaian.

Jika dilihat dari persentase jawaban responden terhadap kompetensi pedagogik guru bahasa Jepang secara umum, dinyatakan bahwa sesuai dengan teori yang dikemukakan oleh walgito (2015) objek yang dipersepsi dalam hal ini adalah guru bahasa Jepang dapat diterima secara rasional dan emosional, sehingga responden akan mempersepsikan positif atau cenderung menyukai dan menanggapi dengan baik sesuai dengan objek yang dipersepsi. Dalam hal ini siswa memberikan penilaian yang baik melalui kuesioner yang diisi terhadap kompetensi pedagogik guru bahasa Jepang dalam proses dan cara mengajar di dalam kelas dengan sesuai. Terbukti bahwa sebanyak $70,32 \%$ responden memberikan pernyataan bahwa kompetensi pedagogik guru bahasa Jepang secara umum sangat baik.

\section{Kompetensi Pedagogik Guru bahasa Jepang pada Tiap-tiap Komponen}

Persentase jawaban responden yang menyatakan bahwa kompetensi pedagogik guru dalam menguasai teori belajar dan prinsip-prinsip pembelajaran yang mendidik dan mampu melaksanakan pembelajaran yang mendidik sangat baik tergolong tinggi yaitu sebesar $61,53 \%$. Guru bahasa Jepang melakukan persiapan akademis maupun non akademis dengan tepat dan menarik sebelum menginjak ke topik pembelajaran, strategi yang digunakan guru dalam mengajar menarik, dan gesture yang menarik sehingga memperjelas topik bahasa Jepang yang sedang dipelajari, bahasa yang digunakan guru sopan dan mudah dipahami dan guru selalu memberikan kesimpulan diakhir pembelajaran. Hal ini sesuai dengan teori yang dikemukakan dalam pedoman Pelaksanaan Penilaian Kinerja Guru Kementrian Pendidikan Jenderal Peningkatan Mutu Pendidik dan Tenaga Kependidikan tahun 2010 dinyatakan bahwa dalam menguasai teori belajar dan prinsipprinsip pembelajaran yang mendidik mampu melaksanakan pembelajaran yang mendidik, seorang guru diharapkan memiliki kemampuan untuk memahami serta menerapkan berbagai pendekatan dalam pembelajaran dan mengaplikasikannya melalui metode dan strategi yang tepat sesuai dengan keadaan dalam kelas.

Hal ini diperkuat dengan hasil wawancara yang menyatakan bahwa kemampuan sudah baik dilihat dari sebelum pembelajaran dimulai, guru selalu membuka pelajaran dengan cerita menggunakan salam dengan bahasa Jepang seperti konnichiwa dan ohayou gozaimasu, guru memancing rasa ingin tahu siswa dengan cara memberikan beberapa pertanyaan yang berkaitan dengan tema yang akan dipelajari. Guru juga dapat mengendalikan keadaan kelas dengan baik sehingga tidak terjadi keributan sehingga proses pembelajaran di dalam kelas dapat berlangsung dengan baik. Guru juga menggunakan strategi pembelajaran yang menarik, tidak strategi yang itu-itu saja melainkan strategi pembelajaran yang bervariasi.

Persentase jawaban responden yang menyatakan bahwa kompetensi pedagogik guru dalam mengenali karakteristik peserta didik tergolong tinggi yaitu sebesar $81,31 \%$. Hal ini menandakan bahwa kemampuan guru dalam mengenali karakteristik peserta didik baik, dimana guru bahasa Jepang dapat memahami karakteristik belajar siswa, guru mengetahui karakteristik belajar siswa berbeda-beda, guru memberikan kesempatan yang sama dalam berpartisifasi aktif dalam pembelajaran, memotivasi siswa tanpa membeda-bedakan, dan guru selalu melibatkan siswa dalam proses belajar mengajar dengan baik. Hal ini sesuai dengan teori yang dikemukakan dalam pedoman Pelaksanaan Penilaian Kinerja Guru Kementrian Pendidikan Jenderal Peningkatan Mutu Pendidik dan Tenaga Kependidikan tahun 2010 dinyatakan bahwa dalam kemampuan mengenali karakteristik peserta didik, seorang guru diharapkan mampu memahami dengan baik karakteristik peserta didik dan menggunakan informasi tersebut dengan tepat dalam melaksanakan pembelajaran dalam kelas. Guru dapat mengatur kelas dengan baik dan memberikan kesempatan belajar yang sama kepada peserta didik.

Hal ini diperkuat dengan hasil wawancara yang menyatakan bahwa kompetensi pedagogik guru bahasa Jepang dalam mengenali karakteristik peserta didik baik, guru mampu memberikan kesempatan yang sama kepada siswa untuk menjawab pertanyaanpertanyaan yang diajukan ke depan kelas, guru memberikan kesempatan yang sama untuk 
siswa berlatih menulis huruf hiragana dan katakana, serta berlatih dialog (kaiwa) ke depan kelas.

Guru sering memberikan arahan dan motivasi apabila siswa melakukan kesalahan dalam melaksanakan pembelajaran di dalam kelas, seperti kesalahan dalam menggunakan pola kalimat. Guru tidak serta merta menyalahkan siswa, tetapi tetap memberikan apresiasi kepada siswa tersebut. Guru juga selalu melibatkan siswa secara aktif dalam pembelajaran, hal ini dilihat pada saat guru memberikan kesempatan kepada siswa yang sudah paham akan materi yang telah diajarkan untuk menjelaskan kembali ke siswa yang belum paham.

Persentase responden yang menyatakan bahwa kompetensi pedagogik guru bahasa Jepang pada kompetensi ketiga yaitu kemampuan guru dalam berkomunikasi dengan peserta didik dikategorikan baik, dimana guru bahasa Jepang dapat berkomunikasi dengan baik, efektif, santun, antusias dan positif dalam berkomunikasi dengan siswa menggunakan bahasa Jepang yang sesuai dengan level belajar siswa dan guru mampu memberikan respon yang relevan terhadap pernyataan yang diberikan siswa. Hal ini sesuai dengan teori yang terdapat dalam pedoman Pelaksanaan Penilaian Kinerja Guru Kementrian Pendidikan Jenderal Peningkatan Mutu Pendidik dan Tenaga Kependidikan tahun 2010 dinyatakan bahwa dalam kemampuan berkomunikasi dengan peserta didik, seorang guru harus bisa berkomunikasi secara efektif, empatik, santun serta bersikap antusias dan postif terhadap peserta didik. Seorang guru harus mampu meberikan respon yang memadai dan sesuai terhadap pernyataan yang diberikan oleh peserta didik.

Hal ini diperkuat dengan hasil wawancara yang menyatakan bahwa kompetensi pedagogik guru bahasa Jepang dalam kemampuan berkomunikasi dengan peserta didik baik. Dilihat dari guru selalu membiasakan dirinya untuk berkomunikasi dengan siswa dengan cara sopan dan santun, guru selalu memberikan respon yang sesuai dengan apa yang dibicarakan oleh siswa. Guru tidak jarang berkomunikasi dengan siswa menggunakan bahasa Jepang di dalam kelas, namun hal tersebut perlu ditingkatkan mengingat bahwa berkomunikasi menggunakan bahasa Jepang dalam pembelajaran sangat penting. Dalam berkomunikasi dengan siswa guru bahasa Jepang selalu mengadakan kontak pandang (eye contack) baik dalam menjelaskan materi dan berkomunikasi langsung. Hal ini dikuatkan oleh teori yang dikemukakan oleh Sanjaya (2016: 40) yang menyatakan bahwa guru yang baik adalah guru yang memberikan perhatian kepada siswa melalui kontak mata. Kontak mata yang terus menerus akan menumbuhkan kepercayaan dari diri siswa.

Persentase yang menyatakan bahwa kompetensi pedagogik pada komponen keempat yaitu mengembangkan potensi peserta didik sangat baik yaitu tinggi, sebesar $67,73 \%$. Hal ini menandakan bahwa kemampuan guru dalam mengembangkan potensi peserta didik dikategorikan baik dan sesuai, dimana guru bahasa Jepang mengetahui dan memberikan kesempatan yang sama kepada siswa untuk mengembangkan potensi yang dimiliki baik dalam bidang akademik maupun non akademik. Hal ini sesuai dengan teori yang terdapat dalam pedoman Pelaksanaan Penilaian Kinerja Guru Kementrian Pendidikan Jenderal Peningkatan Mutu Pendidik dan Tenaga Kependidikan tahun 2010 dinyatakan bahwa dalam mengembangkan potensi peserta didik, seorang guru harus mampu menggali kemampuan yang dimiliki peserta didik, menganalisis dan mengembangkan potensi mereka secara optimal. Guru harus menuntun peserta didik sesuai dengan potensi yang dimiliki peserta didik, sehingga potensi yang dimiliki dapat dikembangkan melalui pembelajaran.

Hal ini diperkuat dengan hasil wawancara yang menyatakan bahwa kompetensi pedagogik guru bahasa Jepang dalam kemampuan mengembangkan potensi perseta didik baik, hal ini dilihat dari peran aktif guru dalam mengembangkan potensi-potensi yang dimiliki siswa. Siswa yang memiliki potensi diberbagai bidang dalam bahasa Jepang seperti potensi menulis huruf hiragana dan katakana dilatih dengan cara pemberian tugas-tugas secara rutin yang kemudian dinilai untuk memberikan apresiasi dari semangat siswa belajar dan tidak jarang diikut sertakan dalam perlombaan.

Persentase jawaban responden yang menyatakan bahwa kompetensi pedagogik guru bahasa Jepang pada komponen kelima yaitu kemampuan dalam melaksanakan penilaian sangat baik tergolong tinggi yaitu sebesar $68,13 \%$. Hal ini menandakan bahwa kemampuan guru dalam melaksanakan penilaian dikategorikan baik, dimana guru bahasa 
Jepang menilai secara rutin sesuai dengan kompetensi dasar yang hendak dicapai, melakukan penilaian sesuai dengan kemampuan siswa, waktu yang digunakan guru dalam menilai sesuai, serta guru melakukan tindak lanjut dari hasil penilaian. Hal ini sesuai dengan teori yang dikemukakan dalam pedoman Pelaksanaan Penilaian Kinerja Guru Kementrian Pendidikan Jenderal Peningkatan Mutu Pendidik dan Tenaga Kependidikan tahun 2010 dinyatakan bahwa dalam melaksanakan penilaian, seorang guru harus mampu membuat instrumen penilaian, melaksanakan proses penilaian dan menganalisis serta memberikan interpretasi terhadap penilaian yang dilakukan terhadap siswa. Penilaian dilakukan oleh seorang guru untuk mengetahui sejauh mana perkembangan kognitif peserta didik.

Hal ini diperkuat dengan hasil wawancara yang menyatakan bahwa kompetensi pedagogik guru dalam melaksanakan penilaian baik, hal ini dilihat dari cara guru mengevaluasi hasil belajar dengan rutin dan sesuai dengan tujuan pembelajaran setiap topik atau tema pembelajaran. Guru selalu memberikan penilaian terhadap hasil-hasil belajar di dalam kelas seperti keaktifan menjawab pertanyaan, berdialog di depan kelas, serta penilaian terhadap tugas-tugas yang diberikan. Guru selalu menandai siswa yang aktif dengan cara memberikan tanda di absen, sehingga membuat siswa semangat. Guru juga melalukan penilaian dengan objektif jadi benar-benar sesuai dengan kemampuan siswa itu sendiri.

Dari persentase jawaban responden terhadap kompetensi pedagogik guru bahasa Jepang dilihat dari komponen kompetensi pedagogik yang pertama sampai kelima sesuai dengan teori yang dikemukakan oleh walgito (2015) objek yang dipersepsi dalam hal ini adalah guru bahasa Jepang dapat diterima secara rasional dan emosional, sehingga responden akan mempersepsikan positif atau cenderung menyukai dan menanggapi dengan baik sesuai dengan objek yang dipersepsi. Dalam hal ini siswa memberikan penilaian yang baik melalui kuesioner yang diisi terhadap kompetensi pedagogik guru bahasa Jepang dalam melaksanakan penilaian dengan sesuai. Terbukti bahwa sebanyak 68,13\% responden memberikan pernyataan bahwa kompetensi pedagogik guru bahasa Jepang dalam melaksanakan penilaian sangat baik.

\section{Kompetensi Pedagogik Guru Bahasa Jepang Ditinjau dari Tiap-tiap Pernyataan Pada tiap-tiap Komponen}

Persentase jawaban yang menyatakan tidak setuju pada komponen pertama yaitu sebanyak $6 \%$. Berdasarkan hasil wawancara, responden memberikan pernyataan tidak setuju terhadap pernyataan no 10 dikarenakan beberapa alasan sebagai berikut: Guru bahasa Jepang tidak selalu menggunakan media pembelajaran, hal ini ditandai dengan kesiapan guru dalam mengajar. Ada beberapa tema pembelajaran yang disiapkan sangat rapi seperti disediakannya video-video, audio, yang mengharuskan siswa mengamati dan menebak apa yang akan dipelajari selanjutnya sehingga minat dan fokus siswa dalam belajar siswa meningkat.

Dari persentase jawaban siswa mempersepsikan bahwa kompetensi pedagogik guru bahasa Jepang secara umum sangat baik dan ada yang mempersepsikan baik. Siswa mempersepsikan atau memandang secara positif kompetensi pedagogik guru bahasa Jepang menandakan bahwa apa yang diharapkan siswa sesuai dengan apa yang guru laksanakan dalam melaksanakan pembelajaran. Hal ini sesuai dengan teori yang dinyatakan oleh Walgito (2015) bahwa persepsi positif merupakan penilaian individu terhadap suatu objek atau informasi dengan pandangan yang positif sesuai dengan apa yang diharapkan objek.

Namun dari persentase jawaban siswa terhadap kompetensi pedagogik guru bahasa Jepang, ada beberapa jawaban siswa yang menyatakan tidak setuju pada beberapa pernyataan yang terdapat pada tiap-tiap komponen, hal ini menandakan masih ada siswa yang mempersepsikan negatif. Persepsi negatif muncul karena ketidakpuasan siswa terhadap apa yang guru lakukan di dalam kelas. Namun dapat disimpulkan bahwa persepsi positif siswa terhadap kompetensi pedagogik guru lebih besar daripada persepsi negatifnya. 


\section{Simpulan dan Saran}

Simpulan yang dapat ditarik berdasarkan analisis data terhadap kompetensi pedagogik guru bahasa Jepang dalam melaksanakan pembelajaran yaitu:

Kompetensi pedagogik guru bahasa Jepang dalam melaksanakan pembelajaran dari persepsi siswa kelas $X$ dan kelas XI secara umum memperoleh skor tertinggi 100 dan skor terendah adalah 73,88. Dari 91 jumlah responden $70,32 \%$ responden menyatakan bahwa kompetensi pedagogik guru bahasa Jepang sangat baik dan $26,67 \%$ menyatakan bahwa kompetensi pedagogik guru bahasa Jepang baik.

Kompetensi pedagogik guru bahasa Jepang jika ditinjau dari tiap-tiap komponen, dari 91 responden menyatakan bahwa kompetensi pedagogik bahasa Jepang dari komponen pertama yaitu menguasai teori belajar dan prinsip-prinsip pembelajaran yang mendidik serta mampu melaksanakan pembelajaran yang mendidik sebanyak $61,53 \%$ responden menyatakan sangat baik. Pada komponen kedua yaitu mengenali karakteristik peserta didik, $81,31 \%$ sangat baik. Pada komponen ketiga yaitu mampu berkomunikasi dengan peserta didik, $83,51 \%$ responden menyatakan sangat baik. Pada komponen keempat yaitu mampu berkomunikasi dengan peserta didik, 63,73\% responden menyatakan sangat baik. Pada komponen kelima yaitu mampu melaksanakan penilaian, 68,13\% responden menyatakan bahwa kompetensi pedagogik guru bahasa Jepang dalam komponen kelima sangat baik.

Berdasarkan hasil wawancara guru bahasa Jepang mampu melaksanakan pembelajaran yang mendidik, dan mampu mengenali karakteritik peserta didik. Guru bahasa Jepang mampu berkomunikasi dengan sopan, baik dalam pembelajaran di kelas atau berkomunikasi secara langsung. Guru bahasa Jepang mampu melaksanakan penilaian dengan tepat secara objektif. Dari beberapa hal positif yang dimiliki oleh guru dalam mengajar, ada beberapa hal yang perlu ditingkatkan. Guru bahasa Jepang diharapkan dapat mengembangkan potensi yang dimiliki peserta didik dengan maksimal.

Saran yang dapat disampaiakan dari penelitian ini diantaranya, Bagi guru diharapkan dapa meningkatkan beberapa hal dalam pembelajaran , sesuai dengan apa yang dinilai dan diharapkan oleh siswa kelas $X$ dan kelas XI sehingga apa yang menjadi tujuan pembelajaran dapat tercapai dengan maksimal. Sebagai seorang guru hendaknya memahami betul aspek-aspek terkait kompetensi pedagogik guru, sehingga dapat mempengaruhi kompetensi-kompetensi keguruan yang lain yang akan berpengaruh langsung pada proses pembelajaran di dalam kelas. Mengingat pentingnya kompetensi keguruan, peneliti lain diharapkan dapat meneliti lebih dalam terkait kompetensi pedagogik dan kompetensi keguruan lainnya

\section{Daftar Pustaka}

Arikunto, S. 2010. Prosedur Penelitian Suatu Pendekatan Praktik. Jakarta: Rineka Cipta

Budiani, Kristian. 2014. "Kompetensi Pedagogik Dosen Jurusan Pendidikan Bahasa Jepang dalam Melaksanakan Pembelajaran di Jurusan Pendidikan Bahasa Jepang Fakultas Bahasa dan Seni Universitas Pendidikan Ganesha Tahun Ajaran 2013/2014" Skripsi (tidak diterbitkan). Jurusan Pendidikan Bahasa Jepang: Universitas Pendidikan Ganesha.

Depdiknas. 2005. Undang-Undang Republik Indonesia, Nomor 14 Tahun 2005 Tentang Guru dan Dosen. Jakarta. Depdiknas RI.

Djamarah \& Aswan. (2002). Strategi Belajar Mengajar. Jakarta: Rineka Cipta

Fattah, Mustamin. 2013 "Kompetensi Pedagogik Guru Bahasa Arab Madrasah Aliyah Se Kota Samarinda" Fenomena, Volume V, No. 1 (hlm 76-77)

Pedoman Pelaksanaan Penilaian Kinerja Guru Kementrian Pendidikan Jendral Peningkatan Mutu Pendidik dan Tenaga Kependidikan.

Rezeki, Ulfah Sari.2015. "Analisis Kemampuan Pedagogik Guru Sekolah Dasar Terhadap Kurikulum 2013 di Kecamatan Medan Area" Tersedia pada http://jurnal.unimed.ac.id/2012/index.php/tematik/index (diakses tanggal 10 desember 2017). 
Riduwan.2011. Skala Pengukuran Variabel-Variabel Penelitian. Bandung: Alfabeta.

Sanjaya, Wina. 2016. Strategi Pembelajaran Berorientasi Standar Proses Pendidikan. Jakarta: Prenadamedia Group.

Sukmadinata, Syaodih. 2008. Metode Penelitian Pendidikan. Bandung. PT Remaja Rosdakarya

The Japan Foundation, 2017. "Laporan Survei tentang Pendidikan Bahasa Jepang diluar Negeri 2015" Tersedia pada https://www.jpf.go.jp/e.project/japanase/survey/result15.html (diakses tanggal 25 Mei 2018)

Walgito, Bimo. 2005. Pengantar psikologi Umum. Yogyakarta: Andi Yogyakarta.

Wendra, Wayan. 2015. Profesi Kependidikan. Singaraja. Universitas Pendidikan Ganesha. 